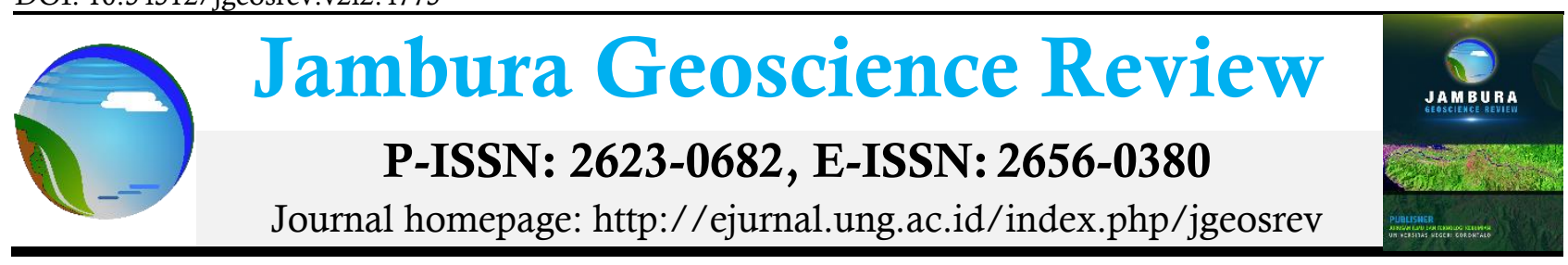

\title{
ESTIMASI PRODUKSI JAGUNG (Zea Mays L.) MENGGUNAKAN PENDEKATAN EKOLOGI SPASIAL DI KABUPATEN JENEPONTO
}

\author{
Laode Muhamad Irsan ${ }^{a}$, Rahma Musyawarah $^{\mathrm{a}}$, Amniar Ati $^{\mathrm{a}}$ \\ ${ }^{a}$ Program Studi Pendidikan Geografi, Universitas Halu Oleo, Kampus Hijau Bumi Tridharma, Anduonohu, Kec. Kambu, \\ Kota Kendari, Sulawesi Tenggara 93232, Indonesia
}

\section{ARTICLE INFO}

\section{Article history:}

Received: 2 March 2020

Accepted: 22 May 2020

Available Online: 10 July 2020

\section{Keywords:}

Climate Parameters; Land

Characteristics; Land Productivity; Land

Suitability; Spatial Analysis

Corresponding author:

Laode Muhamad Irsan

Program Studi Pendidikan Geografi

Universitas Halu Oleo

Email: irsanlibra85@gmail.com

\begin{abstract}
Jeneponto Regency is one of the biggest corn producers in South Sulawesi. Jeneponto Regency is the most suitable area for estimating corn crop production because it is the largest corn-producing region in South Sulawesi Province and has quite complex terrain variations. Agricultural management requires accurate and accurate information or data that can increase productivity and economic benefits. Get accurate and up-to-date data or information about parts of an accurate agricultural information system to support proper planning. The purpose of this study is to map climatic conditions (rainfall) and physical conditions (slope, height, soil type) and to estimate the amount of corn production and maize production maps through spatial assessment. This research was conducted in the Jeneponto Regency, which is located in the southern part of the South Sulawesi Province. The results of the study show that spatial ecology based on agro-ecosystem zones or agricultural unit units in the estimation of special maize production can increase estimation results with high accuracy. Based on the analysis of the four physical maps that have been mapped are rainfall, soil type, slope, and height which are regulated in the agroecosystem zone, the estimated amount with spatial ecological calculations is $159.584,05$ tons. The accuracy of the estimation model results with field data reaches $95 \%$. Based on the results of the study can conclude the results of spatial ecological research can be used as a method of estimating production on corn.
\end{abstract}

Copyright (C) 2020 JGEOSREV-UNG This open access article is distributed under a Creative Commons Attribution (CC-BY) 4.0 International license

\section{Pendahuluan}

Jagung memiliki peran dan kontribusi penting dalam perekonomian nasional, mengingat manfaatnya yang multiguna. Jagung dapat digunakan untuk pangan, pakan, dan bahan baku industri. Jagung penyumbang terbesar kedua setelah padi dalam subsektor tanaman pangan dalam perekonomian nasional (Zubacthirodin et al., 2007). Jumlah kontribusi rata-rata sektor pertanian tiga tahun terakhir 2014-2016 yaitu $13,4 \%$ dan pertumbuhan 3,75\% per tahun. Salah satu komoditas tanaman pangan yang memberikan kontribusi besar yakni kedelai padi, dan jagung (Kementerian Pertanian, 2017).

Produksi adalah indikator penting dalam memantau keberhasilan pengelolaan tanaman yang merupakan output terpenting secara ekonomis. Produktivitas tanaman sangat bervariasi sesuai dengan kondisi lingkungan (iklim, kondisi lahan), kondisi genetik (bahan tanaman dan umur tanaman), dan interaksi diantara keduanya yang berupa pelaksanaan kultur teknis manajemen (Harahap et al., 2000). Pembahasan tentang data jumlah produksi jagung terus berkepanjangan, masing-masing pemangku kepentingan memiliki argumentasi sendiri sesuai dengan kepentingannya. Tetapi, tujuan utama pengelolaan tanaman di negara manapun adalah untuk menjamin sumber daya pangan bagi penduduknya (Soria et al., 2004). 
Saat ini estimasi produksi Jagung umumnya dilakukan dengan cara konvensional yaitu melalui survei lapangan secara langsung. Cara lama ini dalam perolehannya membutuhkan biaya mahal dan waktu yang cukup lama (Jin et al., 2015). Peningkatan produksi dan keuntungan secara ekonomi dapat dicapai jika manajemen pertanian dilakukan dengan baik melalui informasi atau data yang tepat dan akurat (Skakun et al., 2017). Akurasi data dan ketersediaan informasi yang cepat dan mutakhir merupakan bagian terpenting dalam membangun suatu sistem informasi pertanian yang akurat untuk mendukung perencanaan yang tepat. Dalam kaitan ini dibutuhkan suatu basis data yang tidak hanya lengkap tetapi juga mudah diakses serta didukung oleh perangkat yang handal. Berdasarkan konsep dan parameter di atas maka data atau informasi untuk suatu kegiatan atau perencanaan dan pengambilan keputusan yang tepat, diperlukan pemanfaatan teknologi penginderaan jauh dan sistem informasi geografis di bidang pertanian adalah sangat mendukung (Murti, 2014; Irsan et al., 2019).

Pemanfaatan sistem infromasi geografi untuk estimasi produksi pertanian khususnya jagung masih jarang dilakukan di Indonesia. Penelitian tentang perkiraan produksi jagung sering dilakukan oleh negara-negara seperti Amerika, Argentina, Afrika Selatan, Polandia, Hungaria, Kazakstan, India, China dan Meksiko (Soria et al., 2004). Salah satu pendekatan yang digunakan untuk melakukan estimasi produksi yaitu pendekatan Ekologi Spasial. Pendekatan ekologi spasial lebih bertumpu pada fenomena Ekologi Spasial hasil interaksi karakteristik bentang lahan suatu wilayah dengan spesies tanaman yang sesuai. Pola bercocok tanam petani (pola rotasi tanaman) turut dipertimbangkan karena dapat berpengaruh pada jumlah produksi total dalam kurun waktu satu tahun (Danoedoro, 1999).

Kabupaten Jeneponto merupakan daerah yang sesuai untuk dilakukan estimasi produksi tanaman jagung, karena pendapatan sub sektor pertanian tanaman pangan merupakan tumpuan daerah. Selain itu, merupakan daerah penghasil jagung terbesar di Provinsi Sulawesi Selatan serta memiliki variasi medan yang cukup kompleks (BPS, 2017). Variasi wilayah tersebut merupakan salah satu variabel yang diperhitungkan dalam penyusunan model spasial untuk estimasi produksi tanaman jagung.

Pendekatan ekologi spasial memungkinkan untuk memperoleh akurasi yang baik dalam estimasi produksi pertanian. Faktor ini menjadi bahan pertimbangan karena kondisi geografis dan sistem pertanian yang berbeda-beda pada setiap wilayah. Oleh karena itu, diperlukan pengembangan metode dan teknik analisis data yang sesuai dengan kondisi agro-ekologis Indonesia untuk menopang upaya pemetaan dan estimasi produksi pertanian. Jumlah produktivitas pada tanaman jagung dipengaruhi oleh beberapa faktor seperti faktor iklim, faktor fisik (kemiringan lereng, ketinggian, jenis tanah), dan faktor tanaman (pola rotasi tanaman) dapat diturunkan dan dianalisis dengan menggunakan sistem informasi geografi.

Berdasarkan uraian latar belakang dan rumusan masalah yang dikemukakan di atas, maka secara umum tujuan penelitian ini yaitu membuat peta kondisi iklim (curah hujan) dan kondisi fisik (kemiringan lereng, ketinggian, jenis tanah) dan untuk estimasi produksi jagung dan sebaran produksi jagung melalui pendekatan ekologi spasial.

\section{Metode}

\subsection{Lokasi Penelitian}

Penelitian ini dilakukan di Kabupaten Jeneponto Provinsi Sulawesi Selatan (Gambar 1). Penentuan lokasi berdasarkan beberapa pertimbangan yaitu: luas lahan, jumlah produksi, dan variasi morfologi lahan. Kabupaten Jeneponto secara administrasi berbatasan dengan Kabupaten Gowa dan Takalar di sebelah utara, Kabupaten Bantaeng di sebelah timur, Kabupaten Takalar sebelah barat dan laut Flores di sebelah selatan. Wilayah penelitian ini mencakup empat kecamatan yaitu Kecamatan Bangkala Barat, Bangkala, Bontoramba, dan Tamalatea.

\subsection{Metode Penelitian}

Estimasi produksi jagung dalam penelitian diketahui dengan menggunakan pendekatan ekologi spasial, Pendekatan ekologi spasial dikembangkan dari konsep ekologi bentang lahan, Vink (1983), menjelaskan bahwa ekologi bentang lahan merupakan studi hubungan antara fenomena dan proses dalam bentang lahan atau geosfer termasuk di dalamnya komunitas tumbuhan, hewan, dan manusia. Pendekatan ini menurunkan informasi berbagai karakteristik lahan yang ada pada setiap satuan berdasarkan katerkaitan antar struktur, proses dan tahap perkembangan. Pemahaman ini dijadikan dasar untuk mengkaji lebih jauh aspek-aspek spasial fenomena lain yang terkait seperti interpretasi karakteristik batuan, tanah, dan juga hidrologis yang banyak dilakukan dengan pendekatan satuan bentuk lahan, dimana gagasannya tentang morfologi bentang lahan menjadi landasannya. 


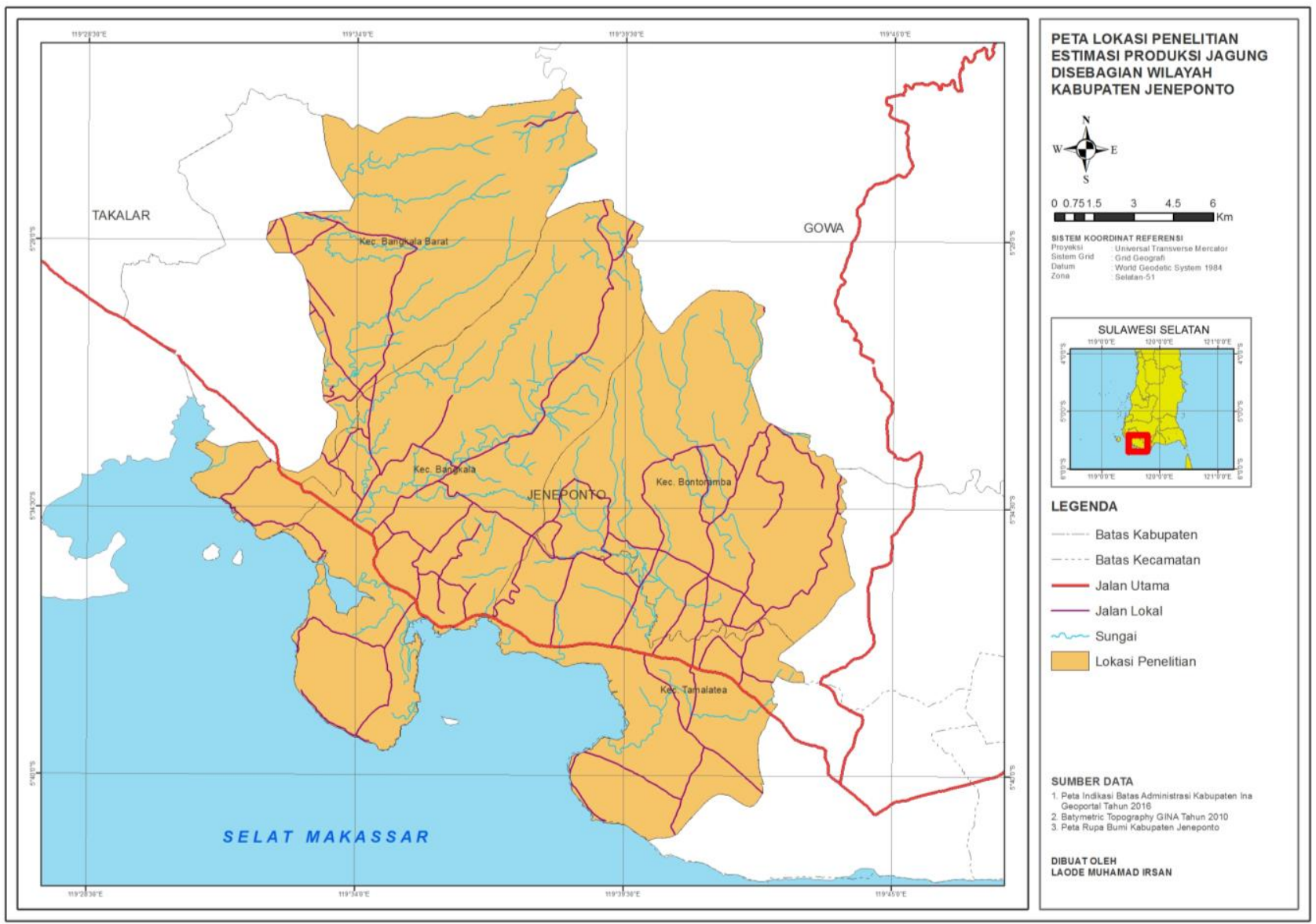

Gambar 1. Peta lokasi penelitian

Estimasi produksi dengan pendekatan ekologi spasial dianalisis menggunakan sistem informasi geografis dengan metode overlay data curah hujan, jenis tanah, kemiringan lereng, ketinggian dan geomorfologi sehingga menghasilkan unit agroekosistem. Penyusunan unit agroekosistem untuk menghasilkan unit-unit produktivitas tanaman dan dibantu dengan pengolahan data sekunder dan pengambilan data lapangan (Murti, 2014). Penyusunan peta agroekosistem untuk memperoleh suatu unit lahan yang memiliki karakteristik lahan, dan iklim tertentu yang berpengaruh pada tanaman jagung. Kemudian agroekosistem diintegrasikan dengan peta penggunaan lahan khususnya lahan yang ditanami jagung, hasil unit yang diperoleh akan mencerminkan kondisi jenis tanaman, dan produktivitas tanaman, sehingga berdasarkan luas unit tersebut dapat dihitung total produksinya (Gambar 2).

\subsection{Analisis Data}

Rangkaian proses interpretasi dan ektraksi informasi data dengan menggunakan sitem informasi geografi (SIG) diuraikan sebagai berikut: a) Penyusunan peta kemiringan lereng dan Elevasi: Peta ini diturunkan dari pembuatan model DSM dengan menggunakan citra ASTER G-DEM. Kedua peta tersebut disusun pada skala 1: 175.000 ; b) Penyusunan peta curah hujan: peta ini diturunkan dari data curah hujan di wilayah kajian yang diperoleh dari instansi terkait, ditambah dengan peta jenis tanah dan peta geomorfologi yang diperoleh dari instansi terkait; c) Penyusunan basis data: Setelah peta dan data tersebut yang digunakan sebagai input selesai dikerjakan, maka tahap selanjutnya adalah penyusunan basis data dan pemodelan spasial dengan metode overlay. Berdasarkan pada data spasial yang digunakan sebagai sumber data, maka basis data yang disusun merupakan data dengan format vektor.

Penentuan sampel menggunakan metode Stratified Spatial Sampling. Sampel dipilih berdasarkan unit agroekosistem yang dianggap mewakili objek tanaman jagung. Penentuan sampel sangat penting karena nilai produksi tanaman jagung yang diambil akan dikorelasikan dilakukan proses korelasi dan regresi langsung disesuaikan dengan unit agroekosistem yang telah dibuat. Jumlah sampel yang diambil pada saat turun lapangan adalah sebanyak 60 sampel. Jumlah sampel tersebut digunakan untuk membuat model zona agroekosistem sebanyak 35 sampel dan untuk uji akurasi sebanyak 25 sampel. Pada setiap plot dicatat jenis varietas, dan jumlah produktivitasnya. Akurasi estimasi produksi 


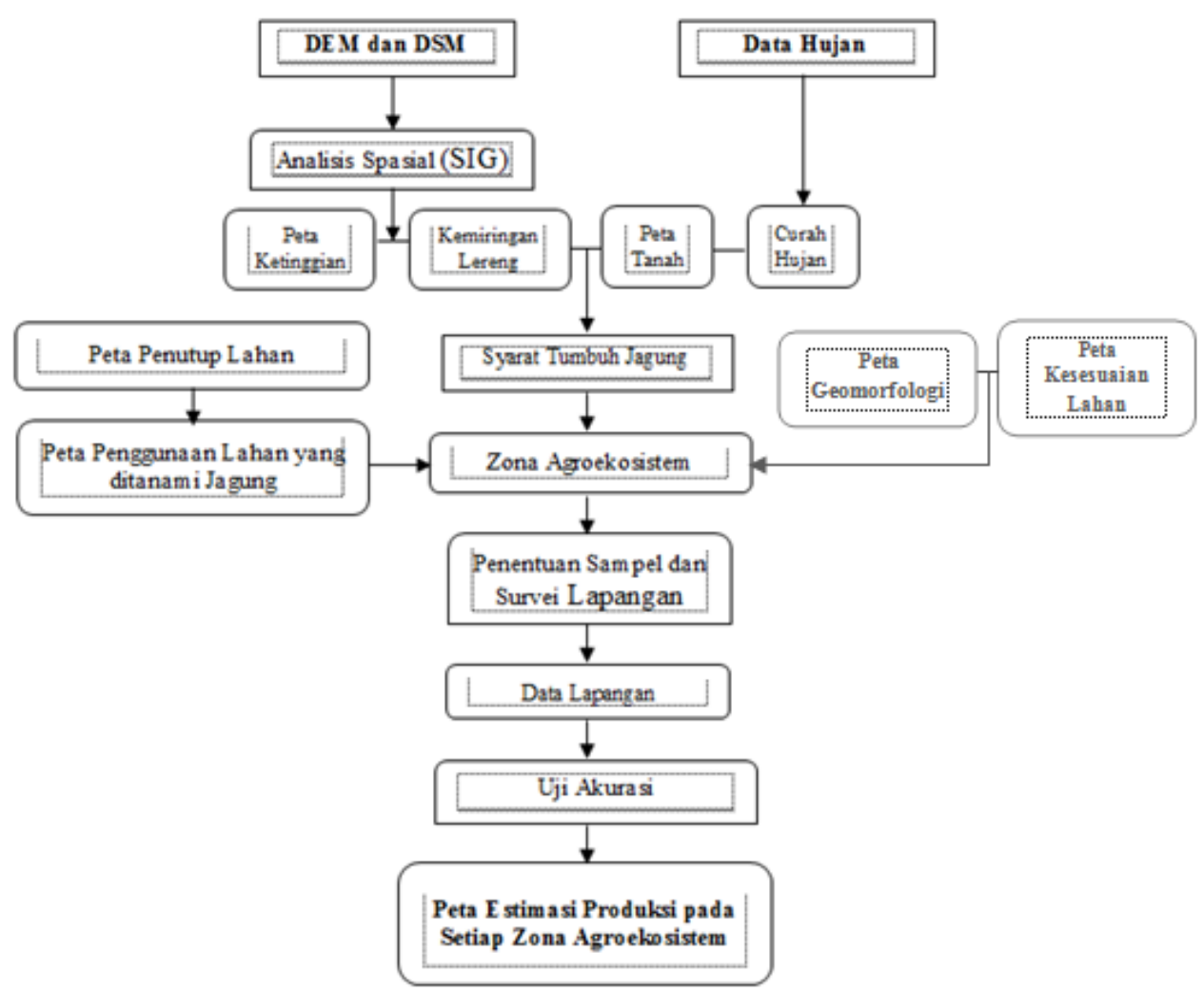

Gambar 2. Diagram alir penelitian

diketahui berdasarkan perbandingan hasil perhitungan model estimasi dengan hasil survey data di lapangan. Survei lapangan dilakukan untuk mendapatkan sampel jumlah produksi yang kemudian dilakukan analisis statistik untuk mengetahui jumlah produksi jagung (Gambar 2). Metode untuk mengetahui jumlah produksi jagung yaitu dengan melakukan wawancara langsung dengan petani jagung yang berada pada lokasi titik sampel yang telah ditentukan sebelumnya.

\section{Hasil dan Pembahasan}

\subsection{Pemetaan kondisi iklim (curah hujan) dan fisik lahan}

Wilayah kajian mencangkup 4 kecamatan yakni Kecamatan Bangkala Barat, Kecamatan Bangkala, Kecamatan Bontoramba, dan Kecamatan Tamalatea memiliki curah hujan rata-rata 1.600 $\mathrm{mm} /$ tahun. Curah hujan terendah terdapat di wilayah Kecamatan Bangkala Barat dan Kecamatan Bangkala dengan curah hujan. Sedangkan curah hujan yang sedang terjadi di wilayah Kecamatan Bontoramba dan Kecamatan Tamalatea hal ini dapat dilihat pada Gambar 3. Peta curah hujan sebagian wilayah Kabupaten Jeneponto. Jenis tanah yang ada di Kabupaten Jeneponto terdapat 6 jenis tanah, sedangkan pada wilayah kajian hanya terdapat 5 jenis tanah yaitu : (a) grumosol kelabu, (b) komplek podsolik cokelat, (c) latosol cokelat, (d) mediteran cokelat, dan (e) regosol cokelat. Dari ke lima jenis tanah tersebut jenis tanah grumosol kelabu, latosol coklat, regosol coklat, Mediteran coklat merupakan jenis tanah yang sesuai dengan tanaman jagung. Sedangkan jenis tanah komplek podsolik coklat masuk pada kategori cukup sesuai.

Kelas kemiringan lereng di wilayah kajian cukup bervariasi dan tersebar hampir semua kecamatan. Kemiringan lereng yang ideal yaitu 0-16\%, lebih dari itu maka perlu dilakukan konservasi atau metode penanaman tertentu. Hal ini karena jika pada kemiringan yang curam akan mempengaruhi tingkat kesuburan tanaman jagung dan saat terjadi hujan yang tinggi rawan terjadi longsor serta rebahan pada tanaman jagung. Dari kondisi kemiringan lereng yang ada, di wilayah kajian cukup potensial untuk ditanami jagung. Berdasarkan hasil pemetaan ketinggian dari permukaan laut untuk wilayah sebagian Kabupaten Jeneponto terdapat 3 kelas ketinggian yaitu $<500 \mathrm{~m}$ yang medominasi hampir seluruh area kajian, 500-700 yang terdapat di Kecamatan Bangkala Barat dan Kecamatan Bontoramba, serta $>700$ $m$ yang terdapat di wilayah Kecamatan Bangkala barat. Dari segi kesesuain lahan untuk tanaman jagung, ketinggian antara 0-700 m masih merupakan ketinggian yang ideal untuk ditanami jagung. Hal ini sesuai dengan pendapat Subekti et al., (2012) bahwa ketinggian kurang dari $600 \mathrm{~m}$ sesuai untuk jenis tanaman jagung. 

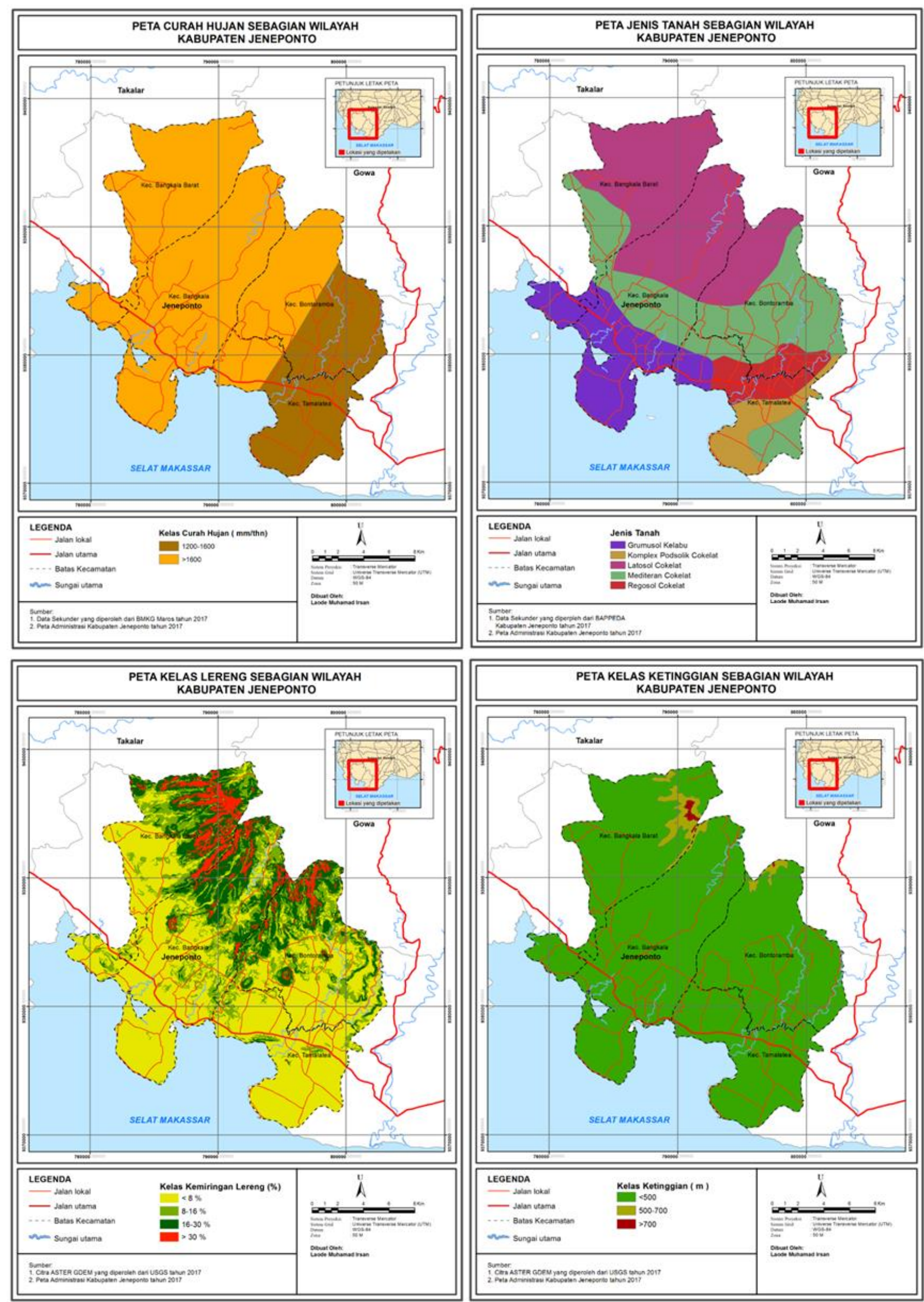

Gambar 3. Peta kondisi iklim (curan hujan), kondisi fisik lahan (jenis tanah, kemiringan lereng, dan ketinggian) di Kabupaten Jeneponto 
Tabel 1. Produktivitas jagung berdasarkan zona agroekosistem

\begin{tabular}{lllll}
\hline No & Satuan Zona Agroekosistem & $\begin{array}{l}\text { Zona } \\
\text { Agroekosistem }\end{array}$ & $\begin{array}{l}\text { Tingkat } \\
\text { Kesesuaian Lahan }\end{array}$ & $\begin{array}{l}\text { Produktivitas } \\
\text { Lahan (ton/ha) }\end{array}$ \\
\hline 1 & $\begin{array}{l}1200-1600,<600,25-40 \%, \text { Regosol } \\
\text { Cokelat, Dataran Tektonik }\end{array}$ & DF1 (Zona-1) & Kurang Sesuai & 3.60 \\
2 & $\begin{array}{l}>1600,<6000-8 \% \text {, Grumusol } \\
\text { Kelabu, Dataran Tektonik }\end{array}$ & DT1 (Zona-2) & Sangat Sesuai & 4.58 \\
3 & $\begin{array}{l}>1600,<600,15-25 \%, \text { Mediteran } \\
\text { Cokelat, Perbukitan Volkan }\end{array}$ & PB1 (Zona-3) & Sangat Sesuai & 5.17 \\
4 & $\begin{array}{l}>1600,<6000-8 \%, \text { Mediteran } \\
\text { Cokelat, Perbukitan Volkan }\end{array}$ & DT2 (Zona-4) & Sesuai & 4.25 \\
5 & $\begin{array}{l}>1600,<600,8-15 \%, \text { Regosol } \\
\text { Cokelat, Dataran Tektonik }\end{array}$ & DT3 (Zona-5) & Sesuai & 4.15 \\
6 & $\begin{array}{l}>1600,<600,8-15 \%, \text { Regosol } \\
\text { Cokelat, Perbukitan Volkan }\end{array}$ & PB2 (Zona-6) & Sangat Sesuai & 4.98 \\
7 & $\begin{array}{l}>1600<60015-25 \% \text { Mediteran } \\
\text { Cokelat Perbukitan Volkan }\end{array}$ & PB3 (Zona-7) & Sangat Sesuai & 4.99 \\
8 & $\begin{array}{l}>1600600-150015-25 \% \text { Latosol } \\
\text { Cokelat, Pegunungan Volkan }\end{array}$ & PG1 (Zona-7) & Sesuai & 4.45 \\
9 & $\begin{array}{l}>1600<60025-40 \% \text { Latosol Cokelat, } \\
\text { Pegunungan Volkan }\end{array}$ & PG2 (Zona-8) & Kurang Sesuai & 3.70 \\
\hline Sumber: Hasil pengolahan data, 2018 & & &
\end{tabular}

\subsection{Pemodelan dengan pendekatan ekologi spasial}

Model estimasi dengan pendekatan ekologi spasial menggunakan data kondisi iklim dan fisik lahan untuk kemudian dilakukan interpretasi pada komponen penyusun unit agroekosistem yang dibantu dengan pengolahan data sekunder serta data lapangan (Murti, 2014). Data yang digunakan untuk penyusunan peta agroekosistem berdasarkan data; pola tanam, rotasi tanaman, curah hujan, jenis tanah, kemiringan lereng, ketinggian, dan geomorfologi yang gabungkan dengan peta tingkat kesesuaian lahan jagung di Kabupaten Jeneponto.

Berdasarkan hasil analisis terhadap keempat variabel kondisi iklim dan fisik lahan yang sudah dipetakan, hasil analisis menunjukan pada lokasi penelitian terdapat empat wilayah agroekosistem dan terbagi lagi menjadi 9 zona yang lebih kecil yaitu dataran tektonik (DT-1, DT-2, DT-3), Jalur aliran sungai (DF-1), Pegunungan Volkan (P-1, PG-2, PG-3,), dan Perbukitan Volkan (PB-1, PG-2). Gambar 4 menunjukan peta zona agroekosistem pada sebagian wilayah Kabupaten Jeneponto. Berdasarkan pada Tabel 1, zona agroekosistem dengan jumlah produktivitas yang tinggi terdapat pada zona PB-1 = 5.17 dengan tingkat kesesuaian sangat sesuai. Produktivitas yang sedang terdapat pada zona DT- $2=$ 4.25 dan produktivitas yang rendah terdapat pada zona DF-1 $=3.60$ tingkat kesesuaian sesuai dan PG$2=3.70$ dengan tingkat kesesuaian kurang sesuai.

Dasar yang digunakan dalam perhitungan jumlah produksi jagung yaitu berdasarkan zona agroekosistem yang telah disusun sebagai unit lahan tanaman pertanian. Dari unit tersebut kemudian infromasi jumlah produksi didapatkan pada setiap titik sampel. Jumlah produksi padi dihitung sesuai dengan rumus yaitu luas taman pada setiap zona agroekosistem kemudian dikalikan dengan jumlah produktivitas pada zona tersebut. Peta penggunaan lahan dijadikan sebagai dasar dalam mengetahui luasan lahan jagung yang berada di wilayah penelitian. Pada Tabel 2. berikut ini menunjukkan jumlah produksi jagung berdasarkan masing-masing zona agroekosistem atau unit lahan di wilayah penelitian.

Berdasarkan Tabel 2 zona agroekosistem diketahui bahwa jumlah produksi jagung tertinggi terdapat pada zona PG2 dengan jumlah produksi $35.335,05$ ton. Sedangkan jumlah produksi jagung terendah terdapat pada zona DT2 dengan jumlah produksi 1.004,18 ton dengan akurasi estimasi $95 \%$. Metode penentuan akurasi estimasi yakni dengan membandingkan hasil perhitungan model agroekosistem dengan hasil survey lapangan. Pada penelitian ini jumlah produksi ini dipengaruhi oleh luas lahan dan produktivitas suatu lahan sedangkan produktivitas disebabkan oleh faktor fisik lahan yang dinilai dari tingkat kesesuaian lahan jagung. Faktor lain yang mempengaruhi jumlah produksi adalah sumber air dan serangan hama serta kemungkinan kesalahan saat pengambilan sampel. Hal ini sejalan dengan pendapat Prasetyo (2017) yang mengatakan bahwa variasi dan distribusi suatu spesies dalam hal ini tanaman jagung dipengaruhi oleh aspek fisik (elevasi dan slope) dan iklim (suhu, intensitas curah hujan). Variabel-variabel ini dipetakan berdasarkan data survey terestris/pengukuran stasiun iklim. 


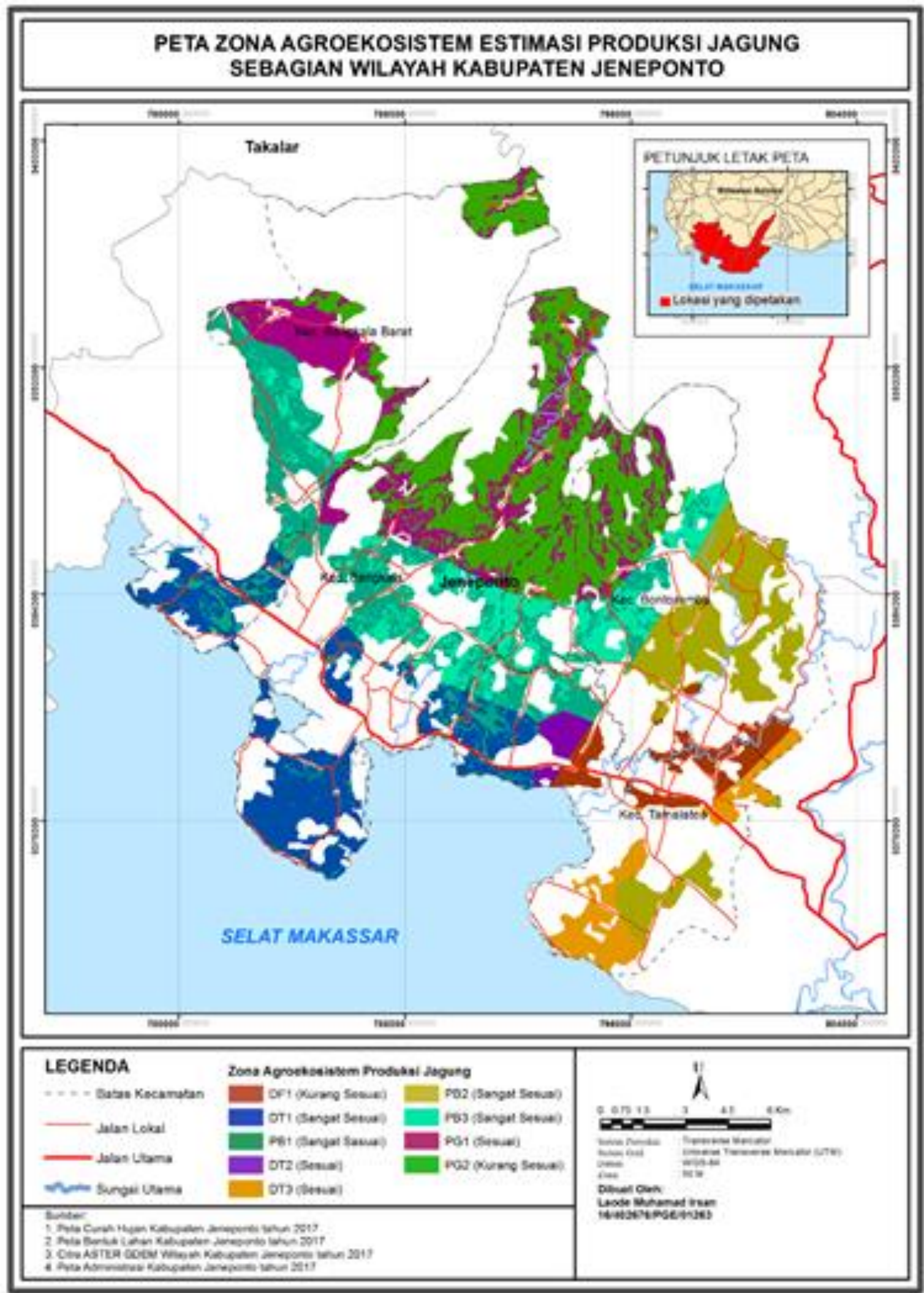

Gambar 4. Peta zona agroekosistem di Kabupaten Jeneponto

Jika dibandingkan dengan penelitian yang dilakukan oleh Irsan et al., (2019), estimasi produksi jagung dengan menggunakan citra satelit Sentinel 2A memiliki perbedaan dari segi pendekatan dan metode perhitungan. Estimasi produksi jagung dengan menggunakan citra satelit Sentinel 2A menggunakan pendekatan spektral, dimana dalam mengitung jumlah produksi berdasarkan nilai piksel dan transformasi indeks vegetasi pada citra sentinel 2A. Sedangkan estimasi produksi dengan pendekatan ekologi spasial menggunakan parameter iklim dan karakteristik fisik lahan yang kemudian dianalisis dengan menggunakan sistem informasi geografi. Hasil estimasi produksi dengan 
Tabel 2. Jumlah produksi jagung berdasarkan masing-masing zona agroekosistem

\begin{tabular}{|c|c|c|c|c|c|c|}
\hline No & $\begin{array}{l}\text { Zona } \\
\text { Agro }\end{array}$ & $\begin{array}{l}\text { Luas Zona } \\
\text { Agro (Ha) }\end{array}$ & $\begin{array}{l}\text { Rerata-Produkstifitas } \\
\text { Tiap Zona (Ton/Ha) }\end{array}$ & $\begin{array}{l}\text { Produksi } \\
\text { (Ton/Ha) }\end{array}$ & $\begin{array}{l}\text { Jumlah } \\
\text { Tanam/thn }\end{array}$ & $\begin{array}{l}\text { Total } \\
\text { Produksi } \\
\text { (Ton/Ha) }\end{array}$ \\
\hline 1 & DF-1 & 763.64 & 3.60 & 2749.11 & 2.00 & 5498.22 \\
\hline 2 & DT-1 & 2682.70 & 4.58 & 12295.69 & 2.00 & 24591.39 \\
\hline 3 & PB-1 & 3641.82 & 4.99 & 18157.07 & 1.00 & 18157.07 \\
\hline 4 & DT-2 & 236.28 & 4.25 & 1004.18 & 1.00 & 1004.18 \\
\hline 5 & DT-3 & 901.35 & 4.15 & 3740.60 & 2.00 & 7481.19 \\
\hline 6 & PB-2 & 2243.42 & 4.98 & 11161.02 & 2.00 & 22322.04 \\
\hline 7 & PB-3 & 1833.81 & 5.17 & 9474.68 & 2.00 & 18949.36 \\
\hline 8 & PG-1 & 2948.92 & 4.45 & 13122.72 & 2.00 & 26245.43 \\
\hline 9 & PG-2 & 4775.02 & 3.70 & 17667.59 & 2.00 & 35335.18 \\
\hline Tot: & 1 Produksi & $19.210,83$ & 4.43 & 89372.65 & 1.78 & 159584.05 \\
\hline
\end{tabular}

menggunakan pendekatan ekologi spasial memiliki akurasi astimasi produksi yang lebih tinggi yaitu $95 \%$, sedangkan estimasi produksi dengan pendekatan spektral memiliki akurasi sebesar $74 \%$.

\section{Kesimpulan}

Berdasarkan hasil dan pembahasan pada penelitian dapat ditarik kesimpulan bahwa: 1) Kondisi iklim (curah hujan) dan data fisik lahan (Penggunaan lahan, jenis tanah, kemiringan lereng, dan ketinggian) di Kabupaten Jeneponto berbeda-beda pada setiap kecamatan. Jumlah curah hujan ratarata kurang dari $1.600 \mathrm{~mm} /$ tahun, hanya terdapat 5 jenis tanah yaitu : (a) grumosol kelabu, (b) komplek podsolik cokelat, (c) latosol cokelat, (d) mediteran cokelat, dan (e) regosol cokelat, tingkat kemiringan lereng dominan 0-16 derajat, sedangkan ketinggian $<500 \mathrm{~m}$ yang medominasi hampir seluruh area kajian; 2) Jumlah estimasi produksi jagung dengan menggunakan pendekatan ekologi spasial yaitu sebanyak 159584.05 ton dengan akurasi atau tingkat kepercayaan estimasi produksi sebesar $95 \%$.

\section{Ucapan Terima Kasih}

Penulis mengucapkan terima kasih kepada semua yang telah ikut membantu dalam penyelesaian penelitian ini. Khususnya Universitas Gadjah Mada dan Badan Meteorologi Klimatologi dan Geofisika Maros yang telah membantu dalam bimbingan dan menyediakan data penelitian.

\section{Referensi}

[BPS] Badan Pusat Statistik. (2017). Kabupaten Jeneponto Dalam Angka. BPS Kabupaten Jeneponto. Tamalatea.

Danoedoro, P., Heru Murti, S., Purwanto, T.H., and Hidayati, B. (1999). Estimasi produksi tanaman peranian yang meliputi: tembakau, padi, dan bawang merah. Universitas Gadjah Mada. Yogyakarta.

Harahap, I.Y., Winarna, \& E.S. Sutarta. (2000). Produktivitas Tanaman Kelapa Sawit: Tinjauan dari Aspek Tanah dan Iklim. Pertemuan Teknis Kelapa Sawit I. Medan: Pusat Penelitian Kelapa Sawit. 25-26 April 2000.

Irsan, L. M., Murti, S. H., \& Widayani, P. (2019). Estimasi Produksi Jagung (Zea Mays L.) dengan Menggunakan Citra Sentinel 2A Di Sebagian Wilayah Kabupaten Jeneponto Provinsi Sulawesi Selatan. Jurnal Teknosains, 8(2), 93. https://doi.org/10.22146/teknosains.36885.

Jin, X., Ma, J., Zidan, W., \& Kaishan, S. (2015). Estimation of Maize Residue Cover Using Landsat-8 OLI Image Spectral Information and Textural Features. Northeast Institute of Geography and Agroecology, Chinese Academy of Sciences, Changchun. China.

Kementerian Pertanian. (2017). Produk Domestik Bruto (PDB) pertanian Triwulan III. Kementerian Pertanian Republik Indonesia: Jakarta.

Murti, S., H. (2014). Pemodelan Spasial Untuk Estimasi Produksi Padi dan Tembakau Berdasarkan Citra Muliresolusi (Kasus Untuk Produksi Padi di Kabupaten Wonosobo dan Sragen, serta 
Produksi Tembakau di Kabupaten Temanggung, Provinsi Jawa Tengah), Disestasi, Universitas Gadjah Mada.

Prasetyo, L., B. (2017). Pendekatan Ekologi Lanskap untuk Konservasi Biodiversitas. Bogor. Fakultas Kehutanan, Institut Pertanian Bogor.

Skakun, S., Vermote. E., Jeans, C. R., dan Belen F. (2017). Cobined Use of Landsat-8 and Sentinel-2A Images for Winter Crop Mapping and Winter Wheat Yield Assesment at Regional Scale, AIMS Geosciences, 3 (2): 163-186.

Soria, R. J., Y. Fernandes dan Rebeca G. R. (2004). Methodology for prediction of corn yield using remote sensing satellite data in Central Mexico. Meksiko: INIFAP.

Subekti, N.A., Syafruddin, R., Efendi, dan S. Sunarti. (2012). Morfologi Tanaman dan Fase Pertumbuhan Jagung. Balai penelitian Tanaman Serealia. Maros

Zubachtirodin, M.S., Pabbage, Subandi. (2007). Wilayah Produksi dan Potensi Pengembangan Jagung. Balai Penelitian Tanaman Serelia. Maros. 